\title{
Impact of a Low Severity Fire on Soil Organic Carbon and Nitrogen Characteristics in Japanese Cedar Soil, Yamagata Prefecture, Japan
}

\author{
Felix Seidel ${ }^{1,2}$, M. Larry Lopez $C^{1 *}$, Georg Guggenberger ${ }^{2}$, Yoshihiro Nobori ${ }^{1}$ \\ ${ }^{1}$ Faculty of Agriculture, Yamagata University, Yamagata, Japan \\ ${ }^{2}$ Institute of Soil Science, Leibniz Universität Hannover, Hannover, Germany \\ Email: *larry@tds1.tr.yamagata-u.ac.jp
}

How to cite this paper: Seidel, F., Lopez C, M. L., Guggenberger, G., \& Nobori, Y. (2017). Impact of a Low Severity Fire on Soil Organic Carbon and Nitrogen Characteristics in Japanese Cedar Soil, Yamagata Prefecture, Japan. Open Journal of Forestry, 7, 270284.

https://doi.org/10.4236/ojf.2017.72017

Received: January 13, 2017

Accepted: April 24, 2017

Published: April 27, 2017

Copyright $\odot 2017$ by authors and Scientific Research Publishing Inc. This work is licensed under the Creative Commons Attribution International License (CC BY 4.0).

http://creativecommons.org/licenses/by/4.0/

(c) (i) Open Access

\begin{abstract}
Slash and burn practices are widely used around the globe with different degrees of success which are mostly related to the impact of fire on soil properties. In Japan slash and burn practises, known as Yakihata, have a long history and are still used in Yamagata Prefecture today. The purpose of this study was to determine the impact of a low severity controlled fire underneath Japanese cedar (Cryptomeria japonica) on brown forest soil (Cambisol). Japanese Cedar is the dominant species among plantations in Japan. We measured organic carbon and nitrogen content as well as changes in carbon $\left(\delta^{13} \mathrm{C}\right)$ and nitrogen $\left(\delta^{15} \mathrm{~N}\right)$ stable isotope composition in a steep west facing slope under heavy precipitation $(\sim 2600 \mathrm{~mm} / \mathrm{a})$ and heavy snowfall $(\sim 3$ to $4 \mathrm{~m} / \mathrm{a})$. The accumulation of $\mathrm{C}_{\text {total }}$ and $\mathrm{N}_{\text {total }}$ at the bottom of the slopes was remarkably higher at the slash and burned site than in the control forest site. After slash and burn $\delta^{15} N$ isotopes in the slope in general became significantly lighter than in the control forest while the $\delta^{13} C$ did not show any significant difference between the two sites except at the bottom of the slopes where $\delta^{13} C$ was heavier in the forest. The results show that $\mathrm{C}_{\text {total }}$ and $\mathrm{N}_{\text {total }}$ values as well as the isotopes ratios of $\mathrm{C}$ and $\mathrm{N}$ change with decreasing elevation in the forest as well as in the burned site being consistent with leaching and erosion. The changes in soil nitrogen and carbon isotopes at the bottom of the slope appear to be related to the transport of material with different isotopic composition from the upper slope. The effect of the low severity fire (as part of the slash and burn practice) on soil organic carbon and nitrogen movement was enhanced by the steepness of the slopes and the high precipitation of Shonai region.
\end{abstract}

\section{Keywords}

High Precipitation, Japanese Cedar Forest Soil, Low Severity Fire, Stable Isotopes, Steep Slopes 


\section{Introduction}

Japan consists of $73 \%$ rugged and mountainous areas which are not suitable for settlement or agriculture and therefore covered by forest (Sasse, 1998; Pohl, 1986). Steep slopes with more than $15^{\circ}$ inclination form $48 \%$ of the country's land mass and slopes with an inclination of more than $8^{\circ}, 71 \%$ (Pohl, 1986). Thus, mountain forests always played an important role in the Japanese civilization, providing the people with food, fuel, building materials, fertilizer and fodder for husbandry in the less steep areas. Nowadays there are more than 10 million hectares (30\% of the total land area) of plantations in Japan, with $44 \%$ Cryptomeria japonica, 24\% Chamaecyparis obtusa and Pinus species as well as Larix kaempferi, Abiessachalinensis and Piceajezoensis covering 30\%.

The Japanese Yakihata is a small scale controlled fire of low severity and intensity that takes place in cedar plantations in a mountainous environment. After the burning root vegetable crops are planted and after their harvest in fall of the same year a new generation of tree seedlings gets planted. Especially in the Japan Sea side of Yamagata Prefecture, which is characterized by heavy snowfall, Yakihata is common and still a wide spread method among local farmers. There are many studies concerning the effect of forest fire on soil chemical composition all over the world (Krasnoshchekov, 1994; Kleinmann et al., 1995; PrietoFernández et al., 2004; Rumpel et al., 2006), but these fires are of high intensity, large scale and not well controlled in flat areas. In contrast, the low intensity fire used in our study area has been poorly investigated.

Fire in steep slopes under heavy precipitation leads to a change not only in available nitrogen but also in carbon cycling and thus humans are directly controlling the carbon and nitrogen balance of these plantations (Tamm, 1991; Vitousek \& Howarth, 1991; Näsholm et al., 1998; Högberg et al., 1996; Perakis \& Hedin, 2002; Magnani et al., 2007; Dagvadorj et al., 2009).

It can alter the amounts and distribution of available nitrogen as well as $\delta^{15} \mathrm{~N}$ ratio due to the change of the soil surface layers' chemical composition and/or the removal of the soil surface layers because of erosion (Hobbie \& Ouimette, 2009). The slash and burn practises in high precipitation and heavy snowfall areas of typical Japan Sea mountain forests offer an opportunity to study the impact of low intensity fires on available nitrogen and $\delta^{15} \mathrm{~N}$ of soils where Japanese cedar seedlings (Cryptomeria japonica) will be replanted and thus, it is essential to know the nitrogen availability of the soils for a suitable growth of the new seedlings.

The aims of this study are to test the following hypotheses:

1) Available nitrogen $\left(\mathrm{NH}_{4}^{+}\right.$and $\left.\mathrm{NO}_{3}^{-}\right)$increases as a result of a low severity fire along the slope but with higher concentrations at the bottom of the slope.

2) Due to high precipitation and heavy snowfall soil organic carbon and nitrogen, as well as carbon $\left(\delta^{13} \mathrm{C}\right)$ and nitrogen $\left(\delta^{15} \mathrm{~N}\right)$ stable isotope composition is not evenly distributed in the slope. This spatial difference is enhanced by a low severity fire. 


\section{Methods}

\subsection{Study Site}

The study site is located in north eastern Japan, Yamagata Prefecture, in the northernmost area of the Asahi Mountains, which are part of the Echigo Mountain Range (N38 $32.362^{\prime}$ E $\left.139^{\circ} 51.701^{\prime}\right)$ with an average annual precipitation of $2558 \mathrm{~mm}$ falling mainly in winter as snow (Figure 1). It is characterised by steep slopes with an average steepness of $68 \%$ making this area prone to erosion if the forest and vegetation cover in the slopes gets slashed and burned (DeBano, 2000).

The fire in our research site was conducted on September $9^{\text {th }}$ 2014. The remnants of the clear cutting (e.g. branches, twigs etc.) were placed on the to be burned area and the fire was started with the burning of dried branches. It was a ground fire of a logged area which is less severe than a wild fire because the intensity and duration is much lower and shorter. Further, the soil is relatively moist because of typically heavy rainfalls in the month before the conducted controlled burning. This moisture promotes a low severity fire and the soil temperatures do not exceed $95^{\circ} \mathrm{C}$ until all water is vaporized; the temperature then does usually not exceed $200^{\circ} \mathrm{C}-300^{\circ} \mathrm{C}$ within the first $5 \mathrm{~cm}$ of mineral soil. Further, nearly no heating occurs below $20-30 \mathrm{~cm}$ soil depth (Certini, 2005).

\subsection{Sample Collection and Treatment}

The sampling sites are situated next to each other being separated by $15 \mathrm{~m}$. The slopes are $75 \mathrm{~m}$ long and in the top parts $30 \mathrm{~m}$ wide. More to the bottom of the slopes, after $40 \mathrm{~m}$ downhill, they narrow to a width of $20 \mathrm{~m}$ due to the natural shape of the slopes. The total difference in elevation is $42 \mathrm{~m}(68 \%)$ from top to bottom in both sites. They were divided into plots of $10 \mathrm{~m}$ by $10 \mathrm{~m}$, only the plots at the very bottom of the slope are $5 \mathrm{~m}$ by $10 \mathrm{~m}$ (Figure 2). The forest site (Control site, $\mathrm{C}$-site) has more trees and a higher tree density than the burned site (B-site) had before fire. Further the trees are more evenly distributed along the slope than in the B-site (Figure 3). The B-site is split into the upper B-site and the lower accumulation area (Acc-area) which can be found at the bottom 5 $\mathrm{m}$ of the B-site.

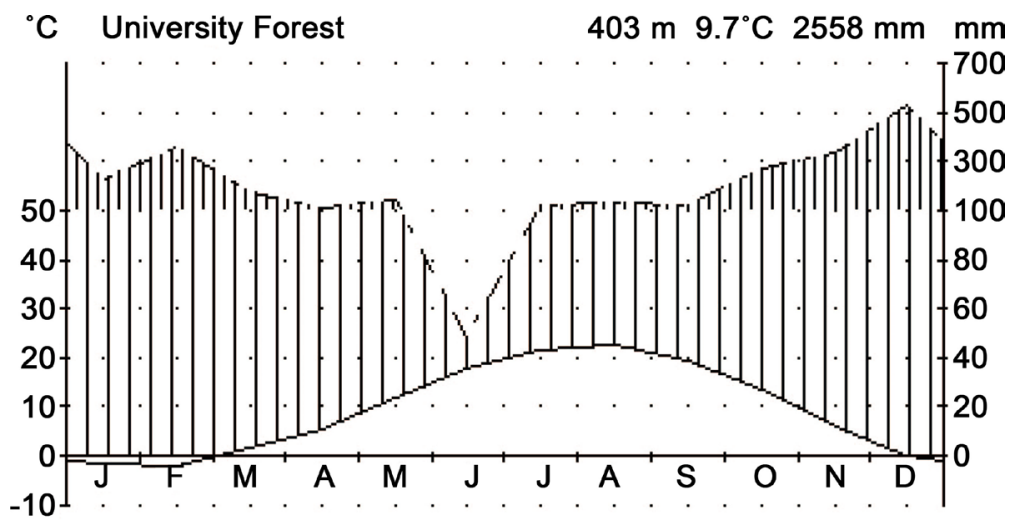

Figure 1. Climate data of the meteorological station in the study site. 

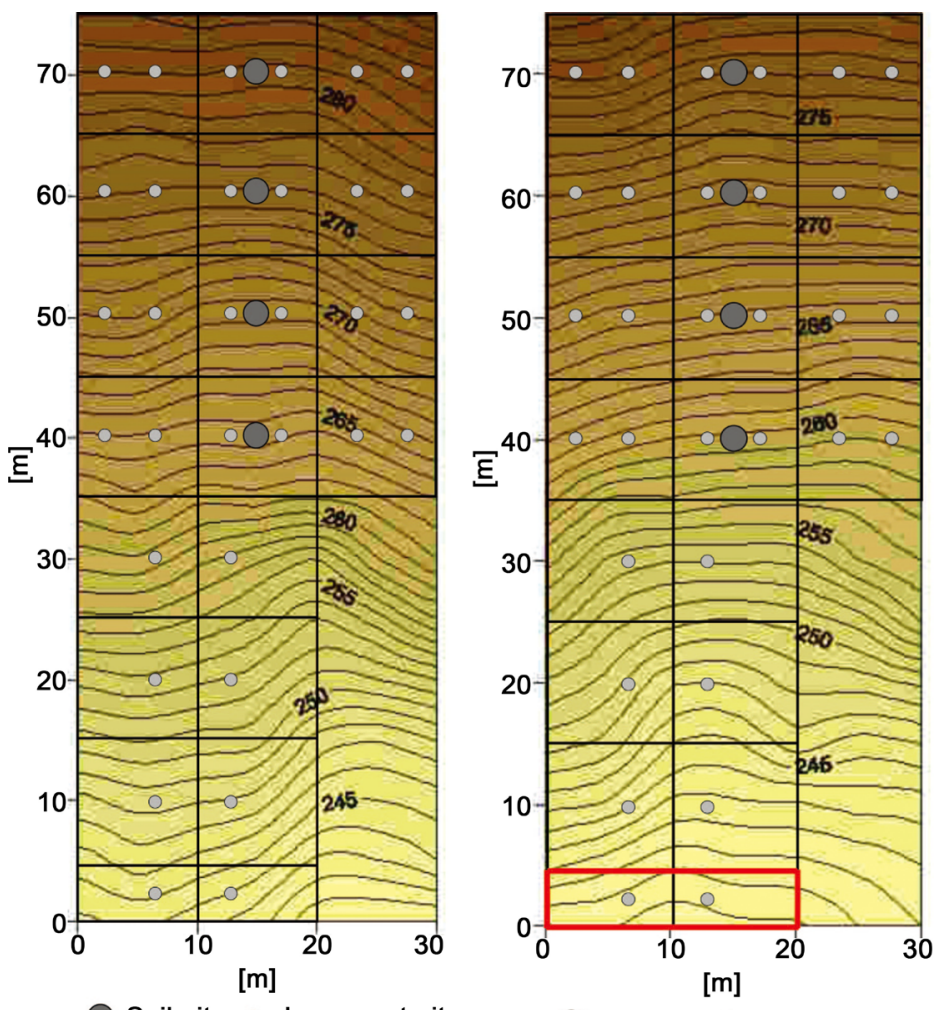

Soil pit $\bigcirc$ Increment pit

Soil pit 0 Increment pit

\section{Accumulation area}

Figure 2. Schematic of the sampling in the forest site (C-site) on the left and the burned site (B-site) on the right.
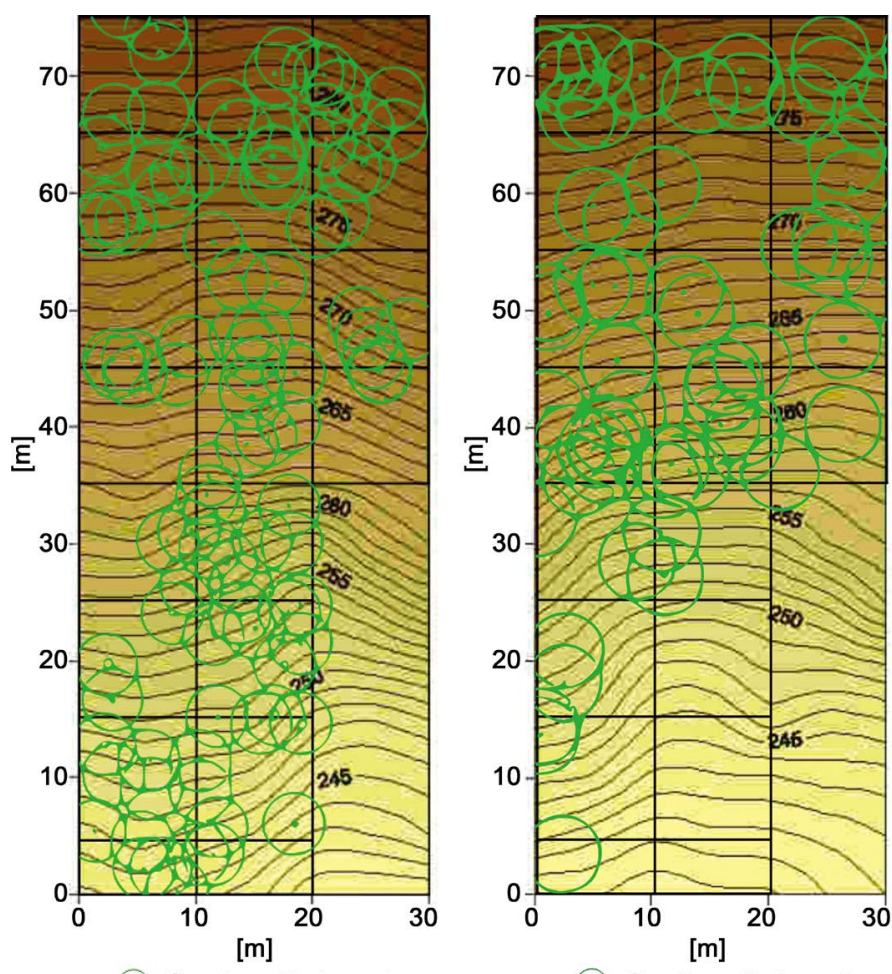

Figure 3. Schematic of tree distribution in the forest site (C-site) on the left and the burned site (B-site) on the right. 
A total of four soil pits $(150 \mathrm{~cm} \times 100 \mathrm{~cm} \times$ max. depth $)$ was dug in the middle line of the top $40 \mathrm{~m}$ for each site. Further, 32 small pits $(30 \mathrm{~cm} \times 30 \mathrm{~cm} \times 30$ $\mathrm{cm}$ ) were dug for an increment sampling to gain more detailed information on both research sites. The amount of samples taken from soil pits in the C-site is 37 while in the B-site it is 32 of which belong 6 to the Acc-area. The number differs due to differences in horizon sequence. 96 increment samples were taken in the C-site, and 96 in the B-site of which 21 belong to the Acc-area.

Soil samples were taken in October 2014 in a steep west facing slope of a Cryptomeria japonica dominated plantation as well as on a freshly burned slope (three months before the sampling) on quartz rough surface rock under brown forest soil. Due to restrictions replication in other sites was not possible, so we used pseudo replication in this study.

Each soil pit was dug up to until solid rock was reached or the ground was too hard to dig without heavy machinery. The profile layers were identified and characterised by colour, grain size and the substrate to classify the soil features. (IUSS Working Group WRB, 2014) (Photo 1 and Photo 2).

For the analysis in the laboratory samples were taken from the identified horizons.

Further, to gain more detailed information on the spatial distribution of measured parameters increment samples were taken from three different depths $(0-1 \mathrm{~cm}, 1-7 \mathrm{~cm}, 7-15 \mathrm{~cm})$.

All samples were stored in plastic bags directly after sampling on October $21^{\text {st }}$ 2014. After transportation from the field to the laboratory the samples were stored frozen until further preparation for analysis. Only the samples for nitrate and ammonium measurement were freshly taken from the field and directly sieved $(<2 \mathrm{~mm})$ and prepared for analysis.

The soil samples were unfrozen, air dried and sieved $(<2 \mathrm{~mm})$. For the total

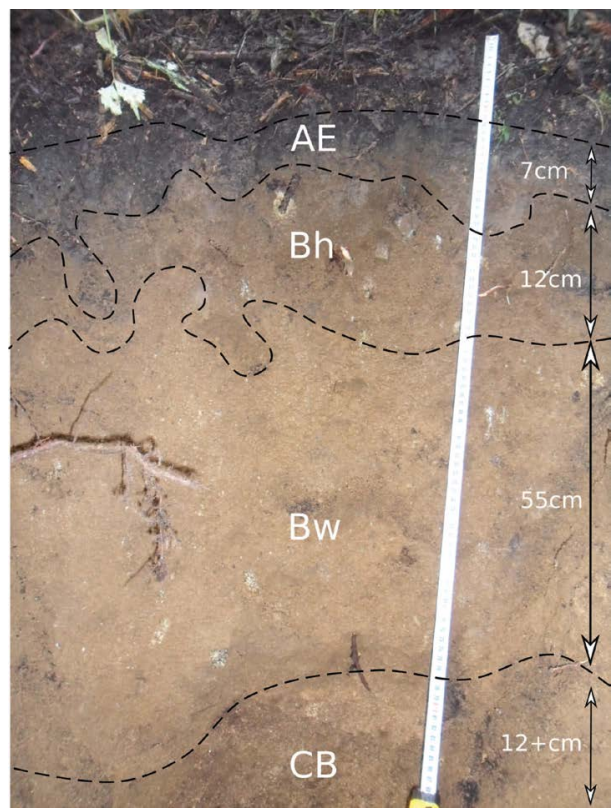

Photo 1. Soil profile of the forest where the horizons can be clearly distinguished. 


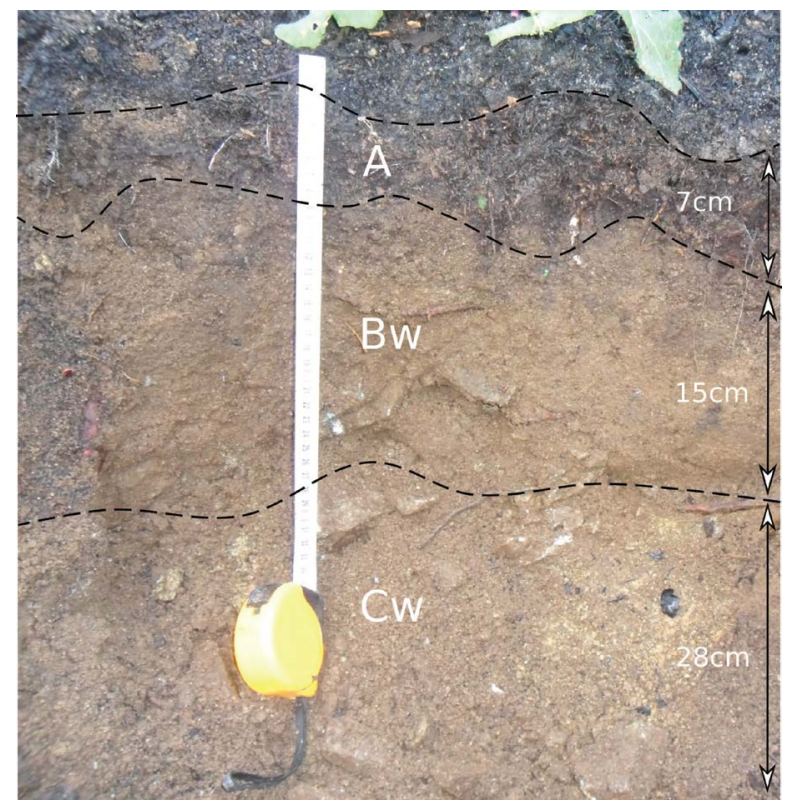

Photo 2. Soil profile of the burned site where the horizons can be clearly distinguished.

carbon and total nitrogen as well as the isotope measurement the samples were unfrozen then air-dried, sieved $(<2 \mathrm{~mm})$, ground and dried in a furnace at $105^{\circ} \mathrm{C}$.

\subsection{Analysing Methods}

\subsubsection{Soil Texture}

Soil texture was measured with the pipette gravitational sedimentation method as described in the BCR Information report (1980).

In order to receive soil texture classes, $10 \mathrm{~g}$ fine material $(<2 \mathrm{~mm})$ was treated with a $30 \%$ solution of $\mathrm{H}_{2} \mathrm{O}_{2}$ in order to remove organic material from the sample. The remaining material was dispersed with $\mathrm{Na}_{4} \mathrm{P}_{2} \mathrm{O}_{7}$ and shaken for at least 3 $\mathrm{h}$ in order to destroy soil aggregates. Silt and clay fractions were determined according to Geeand Bauder (1986) with the distribution of 63 to $20 \mu \mathrm{m}, 20$ to 6.3 $\mu \mathrm{m}, 6.3$ to $2 \mu \mathrm{m}$ and $<2 \mu \mathrm{m}$ fractions. The pipette method was followed by wet sieving to isolate sand fractions of 2000 to $630 \mu \mathrm{m}, 630$ to $200 \mu \mathrm{m}$ and 200 to 63 $\mu \mathrm{m}$. Afterwards, the samples were dried at $105^{\circ} \mathrm{C}$.

The bulk density was measured with a core cutter containing $50 \mathrm{~cm}^{3}$ of soil sample. These cores were weighed, then dried at $105^{\circ} \mathrm{C}$ in a furnace and weighed again.

\subsubsection{Cation Exchange Capacity}

$1 \mathrm{~g}$ of soil was weighed in and $30 \mathrm{ml}$ of a thiourea and silver solution was added. After 1 hour of shaking the samples were centrifuged for 10 minutes at $1200 \mathrm{~g}$. The cation exchange capacity (CEC) was then measured with the AAS Analyst (Perkin Elmer, USA). The Standard was made by Merck (Germany).

\subsubsection{Total Carbon and Total Nitrogen}

All samples were weighed with the A120s (Sartorius analytic, Japan) and $400 \mathrm{mg}$ 
of each specimen was weighed out and put into ceramic shuttles as well as a shuttle containing $100 \mathrm{mg}$ of the standard (Chameleon Reagent DL-Aspartic acid $\left.\mathrm{HOOCCH}_{2} \mathrm{CH}\left(\mathrm{NH}_{2}\right) \mathrm{COOH}\right)$.

For the determination of total carbon $\left(\mathrm{C}_{\text {total }}\right)$ and total nitrogen $\left(\mathrm{N}_{\text {total }}\right)$ a SUMIGRAPH NC-220F automatic high sensitive NC analyzer SCAS was used. The samples and standards were burnt at $870^{\circ} \mathrm{C}$.

\subsubsection{Isotope Analysis}

The samples were weighed with the ME5 high accuracy balance (Sartorius analytic, Japan). The specimens were weighed out between 3.9 and $4.1 \mathrm{mg}$ and folded into tin shuttles. For the determination of $\delta^{13} \mathrm{C}$ ratios and $\delta^{15} \mathrm{~N}$ ratios the Thermo Scientific Flash 2000 Organic Elemental Analyzer, DELTA V ADVANTAGE Isotope ratio MS (Japan) was used. For calibration $1 \mathrm{mg}$ of histidine was used. The samples and standards were completely burnt at $1800^{\circ} \mathrm{C}$.

\subsubsection{Extractable Ammonium and Nitrate}

$10 \mathrm{~g}$ of each fresh sample were weighed (ASP402F balance, AS PRO, Japan) out and $50 \mathrm{ml}$ of $1 \mathrm{M} \mathrm{KCl}$ were added. After one day the samples were filtered and shaken for 30 minutes with the Shaker SA 300 (Yamato, Japan). They were filtered (filter paper No. 6, $125 \mathrm{~mm}$, ADVANTEC, Japan) and stored in a cold dark place for up to four weeks.

The method used for determining ammonium content is taken from Anderson \& Ingram (1989). $10 \mathrm{~g}$ of wet sieved $(<2 \mathrm{~mm})$ soil were treated with $50 \mathrm{ml}$ of $1 \mathrm{M} \mathrm{KCl}$ and shaken for 30 minutes. These samples were treated with two different solutions described in Anderson \& Ingram (1989) during analysis whereas the method for nitrate content was taken from Hayashi et al. (1997). $10 \mathrm{~g}$ of wet sieved $(<2 \mathrm{~mm})$ soil were treated with $50 \mathrm{ml}$ of $1 \mathrm{M} \mathrm{KCl}$ and shaken for $30 \mathrm{~min}$ utes and treated with hydrazine.

The measurement of ammonium and nitrate content was conducted with the U-2900 Spectrophotometer with an attached AS-1010 Auto sampler (Hitachi, Japan).

\subsubsection{Statistical Analysis}

An ANOVA with following Scheffé and Bonferroni \& Holm multiple comparison calculation was carried out to determine the statistical significance of differences in total carbon, total nitrogen, extractable ammonium and nitrate, as well as $\delta^{13} \mathrm{C}$ ratios and $\delta^{15} \mathrm{~N}$ ratiosat the significance levels of 0.5 and 0.1 for the $\mathrm{C}$-site, the B-site and the Acc-area.

\section{Results}

\subsection{Soil}

All dug soil pits are haplic Cambisols according to by the IUSS Working Group WRB (2014) independent of their location. The C-site soil pits are characterized by a horizon sequence of an eluviated top soil layer (AE), followed by a subsoil horizon enriched in humic substances $(\mathrm{Bh})$ and a weathered horizon (Bw). Fi- 
nally, a transition horizon to the parent material (CB) connects. The soils at the B-site is lacking the signs of leaching and the soil pits feature a sequence of an A, $\mathrm{Bw}$ and a weathered parent materialhorizon $(\mathrm{Cw})$ (Table 1). Generally, the soils are sandy with an average pot. $\mathrm{pH}$ of 4.1. The Acc.-area's $\mathrm{pH}$ is more basic than the C-site (Table 1).

\subsection{Total Carbon and Total Nitrogen}

Total carbon and total nitrogen decreased as soil depth increased (Table 2). In general, the $\mathrm{C}$ and $\mathrm{N}$ contents were 1.1 times higher in the soils of the $\mathrm{C}$-site than in the soils of the B-site $(p>0.05)$. Further, the values of the soils of the Acc-area were 1.4 times for $\mathrm{C}_{\text {total }}(p<0.05)$ and 1.7 times for $\mathrm{N}_{\text {total }}(p<0.05)$ higher than in the C-site's soils. Among the elevation gradient contents of $\mathrm{C}_{\text {total }}$ and $\mathrm{N}_{\text {total }}$ in the B-site's soils tended to increase from top to bottom $(p>0.5)$ (top of the slope 24 [mg/g], bottom of the slope $37.6[\mathrm{mg} / \mathrm{g}]$ ) (Table 3 ).

Table 1. Soil properties.

\begin{tabular}{|c|c|c|c|c|c|c|c|c|}
\hline Location* & $\begin{array}{c}\text { Horizon } \\
{[-]}\end{array}$ & $\begin{array}{l}\text { Clay } \\
(\%)\end{array}$ & $\begin{array}{l}\text { Silt } \\
(\%)\end{array}$ & $\begin{array}{c}\text { Sand } \\
(\%)\end{array}$ & $\begin{array}{l}\text { Texture } \\
\text { [WRB] }\end{array}$ & $\begin{array}{c}\text { Bulk density } \\
{\left[\mathrm{g} / \mathrm{cm}^{3}\right]}\end{array}$ & $\begin{array}{c}\mathrm{CEC} \\
{[\mathrm{cmol} / \mathrm{kg}]}\end{array}$ & $\begin{array}{c}\text { potential } \\
\text { pH [-] }\end{array}$ \\
\hline \multicolumn{9}{|l|}{ Control site } \\
\hline \multirow{2}{*}{$\mathrm{C} 1$} & A horizon & 11.1 & 13.7 & 75.2 & LS & 0.7 & 146.8 & 4.5 \\
\hline & B horizon & 3.8 & 14.4 & 81.8 & LS & 1.3 & 38.7 & 4.1 \\
\hline \multirow{2}{*}{$\mathrm{C} 2$} & A horizon & 12.0 & 18.6 & 69.4 & LS & 0.8 & 115.0 & 4.1 \\
\hline & B horizon & 4.7 & 16.4 & 78.9 & LS & 1.0 & 32.9 & 4.0 \\
\hline \multirow{2}{*}{$\mathrm{C} 3$} & A horizon & 9.1 & 19.1 & 71.8 & LS & 0.6 & 118.0 & 4.0 \\
\hline & B horizon & 2.4 & 12.1 & 85.5 & LS & 1.3 & 31.2 & 4.0 \\
\hline \multirow{2}{*}{$\mathrm{C} 4$} & A horizon & 9.2 & 16.5 & 74.4 & LS & 1.0 & 80.1 & 4.1 \\
\hline & B horizon & 8.2 & 15.9 & 75.9 & LS & 1.2 & 55.6 & 4.0 \\
\hline \multicolumn{9}{|l|}{ Burned site } \\
\hline \multirow{2}{*}{ B1 } & A horizon & 6.6 & 12.3 & 81.2 & LS & 0.9 & 73.6 & 4.8 \\
\hline & B horizon & 2.5 & 11.2 & 86.3 & S & 1.1 & 53.4 & 3.9 \\
\hline \multirow{2}{*}{ B2 } & A horizon & 5.7 & 11.6 & 82.7 & LS & 0.9 & 72.3 & 4.5 \\
\hline & B horizon & 3.4 & 11.8 & 84.9 & S & 1.2 & 47.3 & 4.1 \\
\hline \multirow{2}{*}{ B3 } & A horizon & 7.5 & 14.6 & 77.9 & LS & 0.4 & 44.5 & 4.3 \\
\hline & B horizon & 4.8 & 15.5 & 79.6 & LS & 0.9 & 41.5 & 4.3 \\
\hline \multirow{2}{*}{ B4 } & A horizon & 6.1 & 11.2 & 82.7 & LS & 0.5 & 91.9 & 3.8 \\
\hline & B horizon & 3.9 & 12.8 & 83.3 & S & 1.0 & 55.5 & 4.0 \\
\hline \multicolumn{9}{|c|}{ Accumulation area } \\
\hline \multirow{2}{*}{ B5 } & A horizon & 11.6 & 14.9 & 73.5 & LS & 0.7 & 108.6 & 5.1 \\
\hline & B horizon & 9.8 & 14.9 & 75.3 & LS & 1.0 & 40.8 & 3.9 \\
\hline
\end{tabular}

${ }^{*} \mathrm{C} 1$ is found on the top of the slope, $\mathrm{C} 4$ at the bottom. The burned site is divided into the upper area in the slope, referred to as burned site (B1 to B4) and the lower area at the bottom of the slope referred to as accumulation area (B5). 
Table 2. Soil analysis of the soil pit sampling per horizon.

\begin{tabular}{cccccc}
\hline Location & Horizon & $\mathrm{C}_{\text {total }}[\mathrm{mg} / \mathrm{g}]$ & $\mathrm{N}_{\text {total }}[\mathrm{mg} / \mathrm{g}]$ & $\boldsymbol{\delta}^{13} \mathrm{C}[\%$ ] & $\boldsymbol{\delta}^{15} \mathrm{~N}[\%$ ] \\
\hline \multirow{2}{*}{ Forest site } & $\mathrm{AE}$ & $66.1 \pm 44.3$ & $4.2 \pm 2.3$ & $-28.5 \pm 1.5$ & $0.9 \pm 0.7$ \\
& $\mathrm{Bh}$ & $17.4 \pm 2.5$ & $1.4 \pm 0.2$ & $-26.6 \pm 0.9$ & $2.2 \pm 0.4$ \\
& $\mathrm{Bw}$ & $4.9 \pm 1.9$ & $0.4 \pm 0.1$ & $-28.3 \pm 1.1$ & $4.3 \pm 1.8$ \\
& $\mathrm{CB}$ & $0.7 \pm 0.3$ & $0.2 \pm 0.2$ & $-32.5 \pm 0.04$ & $5.3 \pm 1.1$ \\
\hline \multirow{2}{*}{ Burned site } & $\mathrm{Ah}$ & $42 \pm 17.2$ & $2.6 \pm 0.8$ & $-27.5 \pm 0.5$ & $0.6 \pm 0.5$ \\
& $\mathrm{Bw}$ & $10.5 \pm 3.5$ & $0.9 \pm 0.3$ & $-26.8 \pm 0.4$ & $1.3 \pm 0.9$ \\
& $\mathrm{Cw}$ & $8 \pm 6.7$ & $0.6 \pm 0.5$ & $-28.5 \pm 3.0$ & $1.4 \pm 0.1$ \\
\hline \multirow{2}{*}{ Accumulation area } & $\mathrm{Ah}$ & $51.8 \pm 21.3$ & $4.3 \pm 2.6$ & $-27.9 \pm 0.8$ & $1.2 \pm 0.5$ \\
& $\mathrm{Bw}$ & 23.3 & $2.2 \pm 0.3$ & $-25.6 \pm 0.7$ & $2 \pm 0.3$ \\
\hline
\end{tabular}

*The Accumulation area is located at the bottom of the burned site.

Table 3. Soil analysis of the soil pit sampling along the elevation gradient.

\begin{tabular}{cccccc}
\hline Location & Soilpit ${ }^{* 1}$ & $\mathrm{C}_{\text {total }}[\mathrm{mg} / \mathrm{g}]$ & $\mathrm{N}_{\text {total }}[\mathrm{mg} / \mathrm{g}]$ & $\boldsymbol{\delta}^{13} \mathrm{C}[\%]$ & $\boldsymbol{\delta}^{15} \mathrm{~N}[\%$ ] \\
& $\mathrm{C} 1$ & $27.7 \pm 39.4$ & $1.9 \pm 2.5$ & $-28.8 \pm 2.7$ & $3 \pm 1.8$ \\
Forest site & $\mathrm{C} 2$ & $21.1 \pm 14.8$ & $1.6 \pm 1.0$ & $-26.4 \pm 0.8$ & $3.1 \pm 1.7$ \\
& C3 & $47.8 \pm 51.3$ & $2.9 \pm 2.8$ & $-30 \pm 2.1$ & $3.6 \pm 2.9$ \\
& C4 & $13.3 \pm 10.2$ & $1.1 \pm 0.8$ & $-28 \pm 0.8$ & $1.4 \pm 0.5$ \\
\hline Burned site & B1 & $24 \pm 12.9$ & $1.7 \pm 0.7$ & $-26.7 \pm 0.5$ & $0.3 \pm 0.3$ \\
& B2 & $11.2 \pm 10.9$ & $0.9 \pm 0.8$ & $-28.3 \pm 2.0$ & $1.1 \pm 0.3$ \\
& B3 & $29 \pm 29.1$ & $1.9 \pm 1.6$ & $-27 \pm 0.7$ & $1.2 \pm 0.6$ \\
\hline Accumulation area ${ }^{* 2}$ & B4 & $28.8 \pm 28.1$ & $1.8 \pm 1.5$ & $-27.6 \pm 0.6$ & $1.5 \pm 1.3$ \\
\hline
\end{tabular}

${ }^{* 1} \mathrm{C} 1$ is found on the top of the slope, $\mathrm{C} 4$ at the bottom. The burned site is divided into the upper area in the slope, referred to as burned site (B1 to B4) and the lower area at the bottom of the slope referred to as accumulation area (B5); ${ }^{2}$ The Accumulation area is located at the bottom of the burned site

\subsection{Soil Inorganic Nitrogen}

The ammonium content of the increment pits in the C-site was 1.2 times higher than in the B-site's increment pits and in both, it tended to increase insignificantly $(p>0.05)$ with decreasing elevation (C-site 1.3 times higher than at the top, B-site 1.2 times, respectively). The nitrate content of the samples of the C-site tended to be higher than the B-site's samples In the C-site's soils, along the elevation gradient, the amounts were more evenly distributed than in the B-site's soils. There was a decreasing trend from top to bottom (Table 3).

\section{4. $\delta^{13} \mathrm{C}$ and $\delta^{15} \mathrm{~N}$ Isotope Ratio}

The $\delta^{13} \mathrm{C}$ ratio of the research sites' soils all behaved the same; as soil depth increased the isotopes became heavier within the first $30 \mathrm{~cm}$. Further, the soil $\delta^{13} \mathrm{C}$ in the C-site's soils tended to be slightly heavier $(-26.5 \%$ o $\pm 1.1 \%$ o $)$ than the B-site's soils $(-26.7 \%$ $\pm 0.7 \%$ o $)$ and the Acc-area's soils $(-26.8 \%$ o $\pm 1.6 \%$ o $)(p>$ 
$0.05)$.

Within the first $30 \mathrm{~cm}$ as soil depth increased the $\delta^{15} \mathrm{~N}$ isotopes became heavier (Table 3 ). The $\delta^{15} \mathrm{~N}$ ratio of the research sites' soils differed significantly ( $p$ $<0.01)$ from each other; the values of the C-site's samples $(0.6 \% \pm \pm 0.4 \% 0)$ were generally heavier than in the B-site's samples $(-0.3 \% \pm \pm 0.6 \% 0)$. The Acc-area's samples had similar values as the C-site's samples $(0.5 \%$ o $\pm 0.4 \%$ o $)$. For both sites the increment sampling showed that the heavier isotopes were found at the bottom of the slope.

\section{Discussion}

\subsection{Total Carbon and Total Nitrogen}

The data shows a different distribution of the measured parameters along the slope after fire. The climate of this region is influenced by heavy rainfalls in summer and heavy snowfall in winter. In the C-site the vegetation cover seems to protect the soil and nutrients from heavy erosion, whereas the slash and burning of the slope removes this cover (Lopez et al., 2012) and thus seems to strongly increase erosion (DeBano, 2000). Combined with the steepness and length of the slope, as well as the sandy texture of the soil, the removal of the vegetation cover in the B-site due to slash and burn seems to highly promote eluviation and eventually erosion not least because of a higher vulnerability to splash erosion (Renard et al., 1997; Do Socorro da Silva, 1997, DeBano, 2000). Further, the influence of the snow might enhance leaching of cations and reduction of $\mathrm{pH}$ level during the snowmelt period (Guicharnaud \& Paton, 2005).

The values of total carbon and total nitrogen are in agreement with the values found in previous studies for similar research sites in Japan and Norway (Post et al., 1982; Morisada et al., 2003; Callesen et al., 2013; Ugawa et al., 2012). These parameters decreased from top to bottom within the soil mainly because of plant input. Litter fall and its decomposition at the soils surface, as well as processes happening in the rooting zone (e.g. root respiration) are the main source of $\mathrm{CO}_{2}$, $\mathrm{NH}_{4}^{+}$and $\mathrm{NO}_{3}^{-}$and it is important to know the characteristics of the driving factors, which are soil temperature, moisture and rainfall. These factors influence the litter remaining mass and affect surface soil dissolved organic carbon and dissolved nitrogen (Shi et al., 2014; Zhou et al., 2014).

In general, the B-site soils had lower contents of total carbon and total nitrogen than the soils in the $\mathrm{C}$-site, which seems to be a typical sign of forest fires because of the burning of the carbon enriched top soil layer (Certini et al., 2011). Further, it may be linked to leaching and erosion (Renard et al., 1997; Do Socorro da Silva, 1997; Certini, 2005) which may explain why the contents of both, total carbon and total nitrogen are elevated in the accumulation area of the burned site.

\subsection{Soil Inorganic Nitrogen}

High precipitation as well as severe landforms such as steep slopes promote leaching of the highly mobile nitrate ( $\mathrm{NO}_{3}^{-}$) (Hobbie \& Ouimette, 2009). In our 
study site $\mathrm{NO}_{3}^{-}$concentration was in general low in both sites but burning apparently enhanced leaching in the soil as indicated by the lower $\mathrm{NO}_{3}^{-}$concentration in the B-site's soils. The ammonium ( $\mathrm{NH}_{4}^{+}$) distribution, shows similar patterns. Even low severity fires can promote surface runoff by enhancing the hydrophobicity due to a water-repellent top layer parallel to the surface that decreases soil permeability. The moving ashes on the slope can clog soil pores and thus seal the soil surface leading to a decrease in water holding capacity and eventually increasing runoff and soil erosion (Renard et al., 1997; Do Socorro da Silva, 1997; DeBano, 2000; Certini, 2005).

\subsection{Soil Carbon and Nitrogen Isotope Ratio}

The $\delta^{13} \mathrm{C}$ isotope ratio changes with soil depth and elevation; the surface layer is enriched in ${ }^{12} \mathrm{C}$, the deeper layers are enriched in ${ }^{13} \mathrm{C}$. The reasons for differences within the soil layers are humification processes. Through biochemical and abiotic processes, the carbon of organic residues is transformed and converted to humic substances at the soil surface changing in turn the $\delta^{13} \mathrm{C}$ ratio (Quideau et al., 2000; Kramer et al., 2003; Du et al., 2014). Additionally, in the C-site heavier isotopes were found at the bottom of the slope (top of the slope: $-26.5 \% \pm$ $1.1 \%$, bottom of the slope $-25 \%$ o $\pm 0.5 \%$ ), whereas at the $\mathrm{B}$-site $\delta^{13} \mathrm{C}$ became evenly distributed along the slope as shown by the increment sampling which is evidence of depleted carbon material becoming part of the accumulation area.

The result of the $\delta^{13} \mathrm{C}$ soil pit measurement in the C-site showed that the $\delta^{13} \mathrm{C}$ first becomes heavier from the $\mathrm{AE}$ to the $\mathrm{Bh}$ horizon before decreasing with depth. Since the AE horizon is thinner at the bottom of the slope in the C-site a higher number of increment samples taken from the ${ }^{13} \mathrm{C}$ enriched Bh horizon at the bottom of the slope resulting a higher $\delta^{13} \mathrm{C}$ within the first $15 \mathrm{~cm}$ of soil.

In the B-site the distribution of soil $\delta^{13}$ Calong the slope was even because of the origin of the samples; the A horizon is thicker at the bottom of the B-site probably caused by erosion leading to a higher number of samples taken from this ${ }^{12} \mathrm{C}$ enriched horizon (Dzurec et al., 1985; Melillo et al., 1989; Garten et al., 2000; Boström et al., 2007; Du et al., 2014). Further, the fire burned the litter layer and left ashes behind with a heavier isotope ratio (Gonzáles-Pérez, 2004; González-Vila et al., 2001) contributing to a difference in $\delta^{13} \mathrm{C}$ which are then redistributed by rain within the slope.

The $\delta^{15} \mathrm{~N}$ changes with increasing soil depth; the ${ }^{15} \mathrm{~N}$ depleted soil layers are at the top, the ${ }^{15} \mathrm{~N}$ enriched at the bottom. This is in accordance to the literature and there are several mechanisms contributing to these patterns, some of which are litter inputs, fresh belowground inputs and microbial activity (Nadelhoffer \& Fry, 1988; Högberg, 1997; Hobbie \& Ouimette, 2009). The soil $\delta^{15} \mathrm{~N}$ in the B-site however, was significantly $(p<0.01)$ lighter than in the C-site, because of changes in the soil surface chemical composition which has also been observed by Hobbie \& Ouimette (2009). Mainly three factors are controlling the ${ }^{15} \mathrm{~N}$ distribution in soil profiles; the $\mathrm{N}$ transfer by mycorrhizal fungi leading to ${ }^{15} \mathrm{~N}$ depleted plant litter at the soil surface, while enriching the subsoil in ${ }^{15} \mathrm{~N}$ due to 
their habitat at the roots of the host plants. Secondly, ${ }^{15} \mathrm{~N}$ enriched compounds take longer time to get decomposed while ${ }^{15} \mathrm{~N}$ depleted compounds get preferably turned over. Lastly, in non-N limited forest ecosystems like our research site, the $\mathrm{N}$ loss during nitrification might account for large ${ }^{15} \mathrm{~N}$ enrichments with soil depth. Further, along the elevation gradient at the B-site the inorganic nitrogen seems to move down slope depleting the soil of ${ }^{15} \mathrm{~N}$ at the top while the Acc-area gets enriched in ${ }^{15} \mathrm{~N}$. The top is constantly losing inorganic nitrogen, while the bottom enriches, which is evidence of depleted nitrogen material becoming part of the accumulation area and thus, promoting nitrogen availability and aheavier $\delta^{15} \mathrm{~N}$ ratio in the accumulation area in comparison to the upslope situation.

\section{Conclusion}

In summary, the steep slopes in combination with high precipitation in summer and in winter, prompts surface runoff. After the low severity fire, surface runoff seemed to be strongly enhanced as indicated by changes in distribution and concentration of nutrients along the slope. $\delta^{15} \mathrm{~N}$ and $\delta^{13} \mathrm{C}$ values were in agreement with the spatial changes of soil nitrogen and carbon along the slopes after a low severity fire. A significant increase of available nitrogen because of a low severity fire was not observed. Instead, we found a different distribution of the available nitrogen. The growth of cedar seedlings will be probably influenced by the spatial nutrient distribution caused by the low severity fire with seedlings at the bottom benefitting more than those at the top.

\section{Acknowledgements}

This work was supported by funds of the "Leibniz PROMOS" program from Leibniz University, Hannover. I am grateful to Oliver Donnerhack and Ulrike Pieper from Leibniz University Hannover for measuring texture and conducting the CEC analysis as well as Leopold Sauheitl for giving me valuable advice. Furthermore, I want to thank the staff of the University forest of Yamagata University for keeping the site accessible in both summer and winter. Thanks also to Alex Brandtand André Sebastian Schmidtand all the students from the watershed conservation laboratory in the Faculty of Agriculture of Yamagata University.

\section{References}

Anderson, J., \& Ingram, I. (1989). Colorimetric Determination of Ammonium. Tropical Soil Biology and Fertility. Wallingford: ISSS, CAB International.

BCR Information (1980). Certification Report on Reference Materials of Defined Particle Size. EUR $6825 \mathrm{EN}$.

Boström, B., Comstedt, D., \& Ekblad, A. (2007). Isotope Fractionation and ${ }^{13}$ C Enrichment in Soil Profiles during the Decomposition of Soil Organic Matter. Oecologia, 153, 89-98. https://doi.org/10.1007/s00442-007-0700-8

Callesen, I., Nilsson, L. O., Schmidt, I. K., Vesterdal, L., Ambus, P., Christiansen, J. R., Högberg, P., \& Gundersen, P. (2013). The Natural Abundance of ${ }^{15} \mathrm{~N}$ in Litter and Soil Profiles under Six Temperate Tree Species: N Cycling Depends on Tree Species Traits 
and Site Fertility. Plant and Soil, 368, 375-392.

Certini, G. (2005). Effects of Fire on Properties of Forest Soils: A Review. Oecologia, 143, 1-10. https://doi.org/10.1007/s00442-004-1788-8

Certini, G., Nocentini, C., Knicker, H., Arfaioli, P., \& Rumpel, C. (2011). Wildfire Effects on Soil Organic Matter Quantity and Quality in Two Fire-Prone Mediterranean Pine Forests. Geoderma, 167-168, 148-155.

Dagvadorj, D., Natsagdorj, L., Dorjpurev, J., Namkhainyam, B. et al. (2009). Mongolia Assessment Report on Climate Change 2009. Mongolia: Ministry of Environment, Nature and Tourism.

DeBano, L. F. (2000). The Role of Fire and Soil Heating on Water Repellency in Wildland Environments: A Review. Journal of Hydrology, 231-232, 195-206.

Do Socorro da Silva, M., Nilton Curi, L., Granate De Sá e Melo Marques, J. J., \& Sobrinho, F. E. (1997). Evaluation of Characteristics of Cambisols Derived from Limestone in Low Tablelands in North-Eastern Brazil: Implications for Management. Published and presented in 15th World Congress of Soil Science, Acapulco, México, July 1994.

Du, B., Liu, C., Kang, H., Zhu, P., Yin, S. et al. (2014). Climatic Control on Plant and Soil $\delta^{13} \mathrm{C}$ along an Altitudinal Transect of Lushan Mountain in Subtropical China: Characteristics and Interpretation of Soil Carbon Dynamics. PLoS ONE, 9, e86440.

https://doi.org/10.1371/journal.pone.0086440

Dzurec, R. S., Boutton, T. W., Caldwell, M. M., \& Smith, B. N. (1985). Carbon Isotope Ratios of Soil Organic Matter and Their Use in Assessing Community Composition Changes in Curlew Valley, Utah. Oecologia, 66, 17-24.

https://doi.org/10.1007/BF00378547

Garten, C. T., Cooper, L. W., Post III, W. M., \& Hanson, P. J. (2000). Climate Controls on Forest Soil C Isotope Ratios in the Southern Appalachian Mountains. Ecology, 81, 1108-1119. https://doi.org/10.1890/0012-9658(2000)081[1108:CCOFSC]2.0.CO;2

Gonzáles-Pérez, J. A., Gonzaléz-Vila, F. J., Almendros, G., \& Knicker, H. (2004). The Effect of Fire on Soil Organic Matter-A Review. Environment International, 30, 855870.

González-Vila, F. J., Tinoco, P., Almendros, G., \& Martín, F. (2001). Pyrolysis-GC-MS Analysis of the Formation and Degradation Stages of Charred Residues from Lignocellulosic Biomass. Journal of Agricultural and Food Chemistry, 49, 1128-1131. https://doi.org/10.1021/jf0006325

Guicharnaud, R., \& Paton, G. (2005). An Evaluation of Acid Deposition on Cation Leaching and Weathering Rates of an Andosol and a Cambisol. Journal of Geochemical Exploration, 88, 279-283.

Hayashi, A., Sakamoto, K., \& Yoshida, T. (1997). A Rapid Method for Determination of Nitrate in Soil by Hydrazine Reduction Procedure. Japan: Nippon Dojō Hiryōgaku Zasshi, 68, 322-326. (In Japanese with English summary)

Hobbie, E., \& Ouimette, A. P. (2009). Controls of Nitrogen Isotope Patterns in Soil Profiles. Biogeochemistry, 95, 355-371. https://doi.org/10.1007/s10533-009-9328-6

Högberg, P. (1997). ${ }^{15} \mathrm{~N}$ Natural Abundance in Soil Plant Systems. New Phytologist, 137, 179-203. https://doi.org/10.1046/j.1469-8137.1997.00808.x

Högberg, P., Hogbom, L., Schinkel, H. et al. (1996). ${ }^{15} \mathrm{~N}$ Abundance of Surface Soils, Roots and Mycorrhizas in Profiles of European Forest Soils. Oecologia, 108, 207-214. https://doi.org/10.1007/BF00334643

IUSS Working Group WRB (2014). World Reference Base for Soil Resources 2014. International Soil Classification System for Naming Soils and Creating Legends for Soil Maps. World Soil Resources Reports No 106, Rome: FAO. 
Kleinmann, P. J. A., Pimentel, D., \& Bryant, R. B. (1995). The Ecological sustainability of Slash- and-Burn Agriculture. Agriculture, Ecosystems \& Environment, 52, 235-249.

Kramer, M. G., Sollins, P., Sletten, R. S., \& Swart, P. K. (2003). N Isotope Fractionation and Measures of Organic Matter Alteration during Decomposition. Ecology, 84, 20212025. https://doi.org/10.1890/02-3097

Krasnoshchekov, Yu. N. (1994). Impact of Fires on Mountainous Sod-Taiga Soils under Larch Forest in Mongolia. ПОЧВОВЕДЕНИЕ, No. 9, 102-109. (In Russian with English summary)

Lopez, C. M. L., Hatano, R., Guggenberger, G., Ohta, T., Gerasimov, E., \& Fedorov A. N. (2012). Forest Fires Effects on Carbon Stocks and Soil Chemistry in Central Yakutia, Eastern Siberia. Eurasian Journal of Forest Research, 15, 9-17.

Magnani, F., Mencuccini, M., Borghetti, M., Berbigier, P., Berninger, F., Delzon, S., Grelle, A., Hari, P., Jarvis, P. G., Kolari, P., Kowalski, A. S., Lankreijer, H., Law, B. E., Lindroth, A., Loustau, D., Manca, G., Moncrieff, J. B., Rayment, M., Tedeschi, V., Valentini, R., \& Grace, J. (2007). The Human Footprint in the Carbon Cycle of Temperate and Boreal Forests. Nature, 447, 849-851. https://doi.org/10.1038/nature05847

Melillo, J. M., Aber, J. D., Linkins, A. E., Ricca, A., Fry, B. et al. (1989). Carbon and Nitrogen Dynamics along the Decay Continuum: Plant Litter to Soil Organic Matter. Plant and Soil, 115, 189-198. https://doi.org/10.1007/BF02202587

Morisada, K., Ono, K., \& Kanomata, H. (2003). Organic Carbon Stock in Forest Soils in Japan. Geoderma, 119, 21-32.

Nadelhoffer, K. F., \& Fry, B. (1988). Controls on Natural ${ }^{15} \mathrm{~N}$ and ${ }^{13} \mathrm{C}$ Abundances in Forest Soil Organic Matter. Soil Science Society of America Journal, 52, 1633-1640. https://doi.org/10.2136/sssaj1988.03615995005200060024x

Näsholm, T., Ekblad, A., Nordin, A., Giesler, R., Högberg, M., \& Högberg, P. (1998). Boreal Forest Plants Take up Organic Nitrogen. Nature, 392, 914-916. https://doi.org/10.1038/31921

Perakis, S. S., \& Hedin, L. O. (2002). Nitrogen Loss from Unpolluted South American Forests Manly via Dissolved Organic Compounds. Nature, 415, 416-419. https://doi.org/10.1038/415416a

Pohl, M. (1986). Japan-Geographie-Geshichte-Kultur-Religion-Staat-Gesellschaft-Bildungswesen-Politik-Wirtschaft. Stuttgart-Wien: Institut für Auslandsbeziehungen, Thienemanns Verlag. (In German)

Post, W. M., Emanuel, W. R., Zinke, P. J., \& Stangenberger, A. G. (1982). Soil Carbon Pools and World Life Zones. Nature, 298, 156-159. https://doi.org/10.1038/298156a0

Prieto-Fernández, Á., Carballas, M., \& Carballas, T. (2004). Inorganic and Organic N Pools in Soils after Burned or Heated: Immediate Alterations and Evolution after Forest Wildfires. Geoderma, 121, 291-306.

Quideau, S. A., Anderson, M. A., Graham, R. C., Chadwick, O. A., \& Trumbore, S. E. (2000). Soil Organic Matter Processes: Characterization by ${ }^{13} \mathrm{C} N M R$ and ${ }^{14} \mathrm{C}$ Measurements. Forest Ecology and Management, 138, 19-27.

Renard, K. G., Foster, G. R., Weesies, G. A., McCool, D. K., \& Yoder, D. C. (1997). Predicting Soil Erosion by Water: A Guide to Conservation Planning with the Revised Universal Soil Loss Equation (RUSLE). Washington DC: U.S. Government Printing Office.

Rumpel, C., Alexis, M., Chabbi, A., Chaplot, V., Rasse, D. P., Valentin, C., \& Mariotti, A. (2006). Black Carbon Contribution to Soil Organic Matter Composition in Tropical Sloping under Slash and Burn Agriculture. Geoderma, 130, 35-46.

Sasse, J. (1998). The Forests of Japan. Japan: Japan Forest Technical Association. 
Shi, J., Ohte, N., Tokuchi, N., Imamura, N., Nagayama, M., Oda, T., \& Suzuki, M. (2014). Nitrate Isotopic Composition Reveals Nitrogen Deposition and Transformation Dynamics along the Canopy-Soil Continuum of a Suburban Forest in Japan. Rapid Communications in Mass Spectrometry, 28, 2539-2549. https://doi.org/10.1002/rcm.7050

Tamm, C. O. (1991). Nitrogen in Terrestrial Ecosystems (p. 115). Berlin: Springer Verlag. https://doi.org/10.1007/978-3-642-75168-4

Ugawa, S., Takahashi, M., Morisada, K., Takeuchi, M., Matsuura, Y., Yoshinaga, S., Araki, M., Tanaka, N., Ikeda, S., Miura, S., Ishizuka, S., Kobayashi, M., Inagaki, M., Imaya, A., Nanko, A., Hashimoto, S., Aizawa, S., Hirai, K., Okamoto, T., Mizoguchi, T., Torii, A., Sakai, H., Ohnuki, Y., \& Kaneko, S. (2012). Carbon Stocks of Dead Wood, Litter, and Soil in the Forest Sector of Japan: General Description of the National Forest Soil Carbon Inventory. Bulletin of FFPRI, 11, 207-221. (In Japanese)

Vitousek, P. M., \& Howarth, R. W. (1991). Nitrogen Limitation on Land and in Sea. How Can It Occur? Biogeochemistry, 13, 87-115. https://doi.org/10.1007/BF00002772

Zhou, W.-J., Sha, L.-Q., Schaefer, D. A., Zhang, Y.-P., Song, Q.-H., Tan, Z.-H., Deng, Y., Deng, X.-B., \& Guan, H.-L. (2014). Direct Effects of Litter Decomposition on Soil Dissolved Organic Carbon and Nitrogen in a Tropical Rainforest. Soil Biology \& Biochemistry, 81, 255-258.

\section{Submit or recommend next manuscript to SCIRP and we will provide best} service for you:

Accepting pre-submission inquiries through Email, Facebook, LinkedIn, Twitter, etc. A wide selection of journals (inclusive of 9 subjects, more than 200 journals)

Providing 24-hour high-quality service

User-friendly online submission system

Fair and swift peer-review system

Efficient typesetting and proofreading procedure

Display of the result of downloads and visits, as well as the number of cited articles

Maximum dissemination of your research work

Submit your manuscript at: http://papersubmission.scirp.org/

Or contact ojf@scirp.org 